\title{
A Search for Alternative Rural Development Strategy
}

\author{
Dr. Musa Haruna Bwala \\ University Of Maiduguri, Department of Sociology \& Anthropology, P.M.B.1O69, Borno State.
}

\begin{abstract}
The paper set to examine the rural development politicize/programmes of Nigeria government and the result of their implementation. A survey of the existing writings on rural development programmes in Nigeria shows clearly that these policies and programme are counterproductive, because some of the programmes such as the World Bank Assisted Agricultural Development Programme (ADP) and the River Basin and rural development programme which are the 'core' of' Nigeria agricultural and rural development programmes shows clearly that the programmes are counterproductive. Because it is based on International Technology Transfer (ITT), which is deficient in many ways. First, it disregard the felt needs of' the rural $d$ wellers and secondly, it enforce development from above. In other words all the past policies and programmes cannot help in achieving the desired rural development objectives.

The paper then suggested ways of achieving the desired result by proposing the integrated community development approach. This is viewed as the best approach to rural industrialization and should be considered with all seriousness.
\end{abstract}

\section{Introduction}

Rural development is a dominant and most popular theme among policy makers in the world today. Every nation, big or small, is pre-occupied with it (Galtung 1980, [1lich 1980) because it is desirable. Although there is consensus on the desirability of this rural development approach, it adoption varies from one country to the other. While most countries believe that rural development involve the people, others think that development of the rural area can trickle down from lop to the bottom, by simply importing what the planners think is desirable.

Today, the need for the less developed countries to carefully choose the type of rural development strategy that vill benefit their effort is emphasized by even the advocates of the import-substitution industrialization policy. For instance, Nigeria in a bid to achieve rapid rural development took advantage of the "oil Boom of the 1970s to encourage the importation of goods and services that the rural areas cannot sustain with the hope that Nigeria will, through the process, acquire rapid industrialization and rural development.

Despite the industrialization effort and the huge investments and spending towards rural development, most rural areas have remained poor as revealed by ILO (1981) study.

Report from the World Bank also indicated that Nigeria is today, the fifteenth most heavily indebted country in the world. The country's external debt is currently estimated at 31.2 billion dollars, Tn 1988 the figure was close to 30.0 billion dollars representing some 22.0 percent or more than one fifth of the total external debt for the region. The report went on to say that Nigeria is the 13" poorest country in the world putting her on the same rank with Ethiopia and Liberia, and that all the basic indicators used to measure socioeconomic growth show negative performance, and that agricultural production has fallen from 1.7 percent to 1.3 percent, the gross domestic product has fallen from 61 to 0.4 percent showing negative signs of industrialization, dealing a blow to the bogus import substitution policy that has been perused since independence. Further growth in manufacturing has fallen from 14.1 in 1986 to 0.8 this year and the average interest rate on the nations N340 billion debt is above 7.1 percent. The economy is still mono-cultural for oil still accounts for 94 Percent of export earnings meaning that the so- called diversification of other sources of earnings foreign exchange has not been achieved, (World Bank Report, 1996). This shows that our rural and agricultural development programmes and policies embarked by past and present government have not been successful. What has been responsible for this?

This paper believe that a new approach has to be considered in order to be able to solve our rural development problems; the paper therefore advocates the integrated community development approach as an alternative model to the present rural development approach.

\section{The Problem}

The problem of most of the past and present development strategy is its inability to find solution to problems of most of our areas. The question is what is wrong with these development strategies? Many things went wrong and are still going wrong. First and foremost, the task of any rural development policy will be to 
examine and explain the nature of the processes of development and the factors responsible for it, to identify and analyze principal obstacles to development in a given situation and to try to prescribe the most practical and efficient ways of removing such obstacles, so that the various dimension of development can be achieved (Ahmaclu, 1970), Development here is seen as a goal directed and value- oriented activity directed to the optimization of human well-being in all its dimensions (Omar, 1986).

Since man is the active agent of development, so the focus of the development effort and the heart of the development must be man. Development, therefore, means the development of man and his physical and socio-cultural environment. This, human attitude, incentive, tasks and aspirations are as much indices to be considered in policy variables as physical resources, capital, labour, education, skills etc. Thus, development here is seen as multi-dimensional activity not as attempts to isolate one key factor and put an exclusive attention on the other aspect. The integrated community development app roach seeks to consider every factor as equally important to aiding development, hence it strikes a balance between the different developmental factors. In the light of the above analysis, the goal of development policy should consist of human resources development for man is the centre of any development programme, hence development depends on the participation of the individual members of a society, their attitudes, commitments as well as their receptiveness to changes. The first objective of development policy should therefore be human resources development According to Robinson:

Human resources constituted the ultimate basis for wealth of nation, capital and natural resources are passive factors of production: human beings are the active agents who accumulate capital, exploit natural resources, built social, economic and political organizations and carry forward natural development. Clearly in a country which is unable to develop the skill and knowledge of its people and to utilize the in effectively in the national economy will be unable to develop anything else (cited by AVM Larry Koinvan and Prof. Jerry Gana in the Mobilizer Februaiy 28, 1990p. 9.

The development strategy pursued by the past regimes in this country which is informed by this development paradigm has not only succeeded in accelerating the rural-urban drift, but also is undermining the traditional and communal bases of life leading to alienation of the rural dweller. This paper believes that the key element in growth and development is to develop the humans as indicated by the Nigeria Third national Development Plan.

During the third national development plan the federal government attempts to address the situation, by establishing the agricultural and rural development programme which is primarily designed to provide services to small holder farming communities with the view to bringing about social and economic development to the rural areas (Nigeria, 1980).

Indeed the projects succeeded in on small way in draining our foreign exchange. According to The Analyst February 1989, in four years (1980-1983) about \$22 million out of the \$56 million earned from oil was paid out as debt. The consequences of re-paying this debt led to cuts in social services, retrenchment of workers, imposition of taxes, levies and fees, privatization and devaluation of the naira. Indeed this has also aggravated our dependency syndrome to an extent that we depend on the industrially advanced countries for almost all we need. Sometimes spare parts and services meant for such machineries to transform our rural areas are difficult to come by from the manufacturers, so that such machineries get out of use, resulting in huge loses.

Although the problem stressed here has been in favour of adopting indigenous local resources through an articulated co-ordinated integrated community development efforts, that will develop within the people a sense of achievement and confidence in themselves. Such technologies should encourage the people to use their skills and other resources which fit their socio-economic position; this is necessary since a greater percentage of our people who live in the rural areas are poor, it is better to develop consciously, instead of embarking on development that will bring out rapid development which the community can no longer sustain in future.

\section{Conceptual Definitions}

For a proper understanding of the argument presented in this paper, a clear grasp of the basic concepts used will be necessary:

Integrated Community Development in this paper refers to a comprehensive co-ordinated method of all persons and agencies involved in enhancing the social well-being or quality of life of the Nigeria rural dwellers. The use of quality of life in this paper embraces the people's economic, social and cultural conditions. This is a shift from model of development centered on acquiring electronics and arts from Japan and Europe which are based on per capita income as yardstick for measuring social and economic development. (Mardi, F. 1986).

An integrated community development project will incorporate plans arid programmes such as education, health, agriculture and nutrition. Talking about integrated community development in the provision of health care, the World Bank stated that improving health will produce factors of nutrition, education, sanitation, water, occupational safety, personal health care, control of disease vectors and mass immunization (Musa, 1997). If this example is acceptable, then it implies that integrated community development as strategy in our socioeconomic development must be taken seriously as a panacea to rural development. Integrated rural development 
is very vital because it emphasizes enhancing the quality of life of our people, because all the other rural development approaches have failed. Integrated community development as advocated in this paper is different from current practice. In my view, it will focus not only on mobilization of the human and material resources towards achieving overall social well-being of our rural populance but on social policy, education and training.

\section{Nigeria Rural Development Programmes: An Appraisal}

Most Nigeria rural development policies past and present are executed without any consultation with or the participation of the rural dwellers; because of the irresponsiveness of Nigeria rural development policies to rural problems and the non recognition of the rural dwellers. Idachaba (1980) asserted that rural development programmes in Nigeria are not designed to benefit the rural dwellers but to satisfy the needs of the urban political elite (military or civilians) and that no attempt is made to integrate the Nigeria rural dwellers into the main stream of national planning and development. This does not mean that the rural dwellers are not contributing to National development. In fact, Musa (1989) revealed that over 95 percent of Nigeria's food crops comes from the rural small scale farmers. Olayide (1980) did believe that the past rural development policies did not motivate the rural farmers and rural dwellers. He lamented the absence of consultation with the farmers and disregard to the millions of small-scale farmers scattered all over the country on rural and agricultural development policies. While idachaba (1980) believed that Nigeria's rural development policies are only panic measure meant to solve the problems of rural political economy, Writers like Ogunnika (1985) Olayide (1980) and Esang (1971) have documented that these policies have failed because of corruption, they submit that the operation Feed the Nation (OFN), the National Accelerated Food Production (NAFAP) the Green Revolution (GRP), the River Basins Development Authority (RBDA) the Agricultural Development programmes (AJ)P), the Better Life for Rural Development (BURD) the National Agricultural Land Development Authority (NALDA), and the Directorate for food, Road and Rural Infrastructure (DEFFRI) were seen as conduit pipes meant to siphon public funds into private pockets. Some writers like Ogunnika (1989) Olayide (1980) have emphasized the effectiveness of the Agricultural Development programmes (ADPS) and the River Basin Development Authority (RBDA). The major argument of these writers was that rural development could be best approached from the standpoint of the small farmers especially in rural development and this is why they (the agricultural development programmes) could not achieve much; because of lack of autonomy.

They always dance to the dictates of their financier and hence they could only execute the projects the World Bank believes is good for Nigeria's economy. This is a serious limitation which hinders the productivity of those organizations too; it is on these ground that this paper proposes a new approach to rural of rural development and will be development policies that concerns them and resources allocated to rural areas are utilized to meet the social and economic needs of the people.

\section{Achievements So Far}

\section{Nigeria Agricultural Development Programmes}

This section will not attempt a general review of all the rural development programmes in Nigeria, but rather an attempt will be made to review the ADPs and RBDA agricultural development model, which are the two most gigantic agricultural development programmes in Nigeria, whose presence are virtually felt in oil states of the federation.

\section{THE ADP AND RBDA Development Model}

The impact of the ADP and RBDA towards rural development in Nigeria is very minimal. The strategy has been criticized for a number of reasons. We will attempt to review some of the ADP and RBDA rural development effort. it is worth mentioning that almost all agricultural and rural development efforts in Nigeria are based on the International Technology Transfer (ITT) and very many have failed woefully.

The River Basin Development Authorities (RJ1DA) and Agricultural Development Programmes (ADPS)

These are capital intensive programmes one of whose function is to develop the rural areas and to increase agricultural productivity through the supply of input, manpower, irrigation and other Supports which farmers could not normally obtain by themselves. The River Basin Development Authority (RBDA) has been active in developing irrigation projects and pilot farms. The project was set up to provide food and raw materials based for the establishment of agro-based industries. Similarly, huge and expensive dams, irrigation and infrastructural land clearing equipment were established. The Agricultural Development projects (ADPS) are similar to the River Basins Development Authority (RBDA), the components to the project are crops, land clearing, rural and road construction, tractor hire, farmers/staff training and inputs distribution. There are indications that the ADP and the RBDA has achieved some little success Bala, (1980,) Ogunmika, (1986) The RBDA have contributed to the provision of water for rural populance and have substantially been said to contribute to the improvement of the income and living standards of the farmers in the project areas. But this does not mean that the project has 
succeeded in their rural development. Research in this area, Alkali (1986) has concluded that "actual experience to date has confirmed beyond reasonable doubt that the project have benefited large scale progressive farmers, rather than the majority of the peasantry." This has been succinctly expressed by Alkali when he said:

There is very little evidence that the recent World Bank agricultural development projects have benefited the poorest farmers or have been intended o do so. There is evidence that the benefits of this World Bank loans have accrued to the rich rather than the poor and that some projects have excluded the poor from access to productive resources and redistributed assets and income to the rich. (Alkali,1986). Other areas by which the ADP and RBDA were criticized of little or no success are:

a. Political and economic independence.

b. Nutritional status of farmers and food security.

c. Political and social development of the people.

d. Self-sufficiency.

\section{Political and Economic Independence}

Political and Economic Independence is the dream of all countries. Any project, programmes or processes that is not geared towards a balanced political or economic independence are obviously detrimental to the peoples existence Sa'a \& Dicta, (1986). Indeed the aim of setting up programmes of this nature is to enable the people become self-reliant in basic food and raw materials requirement which ultimately is the prerequisite to political and economic independence. However, projects like the ADP and the RBDAs are far from giving the desired political and economic independence. Sa'ad \& Dicta (1986) said the ADP and RBDAs are:

Programmes or projects that are initiated and executed from outside and based on the felt needs of the initiators such as the ADPs are generally neo-colonising in nature.

The ADPs are projects jointly owned by the World Bank and the Nigerian government. The World Bank provides a substantial amount of the funds required to execute the projects, as such she dictates the pace of the programmes. Indeed 80 percent of the World Bank appointees owe allegiance to no government but the World Bank and so the needs and aspirations of the World Bank is better understood by the appointees rather than that of the Nigerian people.

The RBDA whose projects and programmes are initiated within but executed through foreign "exports and local collaborators, are equally neo-colonising in nature. Both programmes and projects (ADP \& RBDA) cannot bring the much desired political and economic independence, this indeed is the major cause of their non achievements of intergrated rural development in Nigeria.

\section{Food Security and Nutritional Status}

It has been emphasized that the ADPs Jay emphasis in the production of cereals and tubers to the neglect of livestock and fish and even grain legumes such as cowpea and especially groundnuts. Raza, (1982,) Sa"a Dicta, (1986). By this action, the nutritional status of the farm families has worsened since its inception (Raza, 1982). This is not surprising said Sa'a and Dicta because it is mixed farming and mixed cropping does not ensure nutritional balance in most rural societies.

A project or programme which emphasizes on only one aspect, that is, sole cropping of cereals, roots and tubers, is bound to cause serious nutritional problems for the farm families; instead of the ADPS "integrating" they are disintegrating, Sa 'a\&Dicta (1986, p. 8).

The deliberate exclusion of grain limes, fisheries and livestock in some propose-wide ADPS in Nigeria, is a clear indication that the world bank is not only insensitive to the felt needs of the beneficiaries of the aid but that it does not recognized that food and nutritional policies has to be taken seriously if development has to take place.

The RBDA has been nearest to rural development in Nigeria said Akinyosoye (1984) but he lamented that their livestock and fisheries programmes have however been more of direct production rather than assisting the farmers to produce and as can be expected the performance has been relatively poor. Another criticism of the $\mathrm{ADP}$ and RBDA is the inability to handle food processing and storage facilities.

\section{Politica1 and Social Development}

Writers like Griffin, (1979), D'Silva and Kaza (1983) state that the ADP and RBDA have worsened the political and social development of the people. It polarizes the community and creates alliances and is typical of many developing countries. The richer peasants align with the elite and local bureaucrats to corner the benefits derivable from innovations as observed by Van Velzen (1976) and Ojo (1977) coalition of the rich peasants and government staff posted to the rural areas ensures that attempts by government to stimulate rural development, benefit only the upper strata of the peasantry. The poorer farmers who form a larger majority and the most productive group in terms of physical production are not even aware of their political power let alone exercise it. 
The progressive farmer concept with the "trickle down theory is therefore a political (and economic) weapon used in preventing the political development of the majority of developing countries because, they the governments, and their bureaucrats detest the sharing of political power with progressive groups. Sa'a and Dicta (1986 p. 10,).

Gana (1984s) also lamented on such negative behaviour, when he said:

Many promising rural development projects are usually aborted or discouraged by governments and their agents (the bureaucrat and technocrats) when they realize that the end result will be the wielding (or sharing) of political power by farming committees (p. 10).

Indeed, the ADPs and RBDA have tried, mainly on paper to encourage the farmers and develop the rural areas. It can be observed that both the two programmes fail to organize women into productive activities, is again seen as a deliberate attempt to ignore the larger majority of the productive population. This is why some writers believe that the two programmes benefited only the men with the believe that it will trickle down to women and children from the head of households who are almost always men (Decree, 1985) very little trickle down to the men and children did happen said Sa'ad and Dicta (1986:10).

\section{Self-Sufficiency}

There are claims that the ADP and RBDA have benefited the farmers or have been intended to do so. According to Alkali (1986):

The first generation of the Agricultural Development Project (ADPs), at Futua, Gasau and Gombe, was launched in 1975 but very few people knew about it. Ten years after its establishment with more than 13 fully fledged ADPs under implementation and seven ne $\mathrm{v}$ ones coining up, majority of Nigerians are yet to feel the full impact of the objectives behind the establishment of the projects. p. 11)

The River Basin Agricultural Development project has not been of much difference, there are cries of much government spending. Musa (1989) find Out that between 1976 to the end of 1982, government spent a total sum of N2.78 billion on the RBDAs but with little claim by farmers on self sufficiency or nearly so. This includes rice, wheat, and poultry feeds among others.

The RBDAs has also led to massive dislocation of the peasantry from their settlements and farmlands to make way for irrigation projects. According to Alkali (1986):

In one of the projects in Bakoloridam, hundreds of displaced peasant families were massacred by mobile police squads on Saturday $26^{\text {th }}$ April, 1980 for c/tiring to complain of inadequate and even lack of compensation for the land and properties they lost.

Beside these outcry, there was the complain of sophistication of equipments used by the river Basins, which was not easy to maintain because of the high cost of the spare parts. According to Omar (1987), all integrated rural development approach that has the interest of the people at heart must take the task of development into their hearts and start shaping appropriate structures and initiating appropriate processes. He (Omar) concluded that all development approach geared toward the upliptment of the lives of the people must have the following features. (Omar, 1987, p.9)

a. Localized community based efforts.

b. Collective self-reliance.

c. Appropriate technology.

d. Focus on human needs

e. Respect for culture.

f. Preservation of eco-system.

g. Participation.

h. Non-alienating organization of production.

i. Mutual help and co-operation.

Omar is of the belief that most of the rural development policies that have success stories of development like the Soviet Union, China, Japan, Cuba, Taiwan, Korea, Singpore, Yugoslavia consider most, if not all, of the above essential features which the RBDA and ADP cannot boast of having even one of the stated Features.

\section{The Alternative Approach}

Disappointed by the ADP and RBDA's rural development strategy, some scholars Ogunnika, (1986,) and Gana (1984) have been advocating for alternative rural development strategy. Perhaps the most indisputable approach to rural development acknowledged by even the United Nations is the integrated Community Development Approach. In the integrated community development the workers carry the people along with them both in the planning and implementation. There is never a situation of planning from the above, the people must be involved, and the planning should take into consideration the linkages and inter relationship between the various components such as cooperative Movement, Labour Union, Red Cross Society and even the NYSC. 
This approach must be holistic in which it can incorporate technical fields such as agriculture, health or cottage industry. Irrespective of these technical fields, the emphasis must be on social process of involving the people in defending their needs and how their problems can be solved through local planning and action, and of executing the plan through minimal cost and local resources.

The technical agencies programmes should be involved and identified with the people's ability to solve their own problems without dependence on the government to do it for them as is often the case today. As Donor rightly observed: No project which affects socio-economic change can possibly succeed if the recipients do not participate, since ultimately it will be their responsibility to continue it. (Donor, 1984).

Community development is a concept and a strategy that could be utilized in planning and implementing development programmes. It is multi-disciplinary in character and involves the sum total of all the development programmes in a country. There is also a negative feeling that local communities are parochial by nature and concentrate on their own interest. This is why some group thinks that community development is too slow and inefficient way of development and advocates a concentrated use of force and education from the side of government for the wellbeing of the people. But we argue here that human beings cannot be seen to be handled as instruments, it is not only the physical development that matters but also the human progress and this cannot be obtained by the use of force and the only way to execute a project without any apathy, opposition, and resistance towards the government is through community development approach. The integrated community development approach being advocated here uses the society as the foundation and rationale for development planning.

The community development takes cognizance of the political, cultural, economic, technological, legal, educational, and social elements. It is through these social value ideals and needs derived from the society's social system along with socio-economic resources that the integrated community development is developed. The majority contribution of the integrated community development approach is its ability to make human life and effort purposive and value oriented, There is no doubt that economic development cannot be of any meaningful purpose unless it embodied the culture, economic, technological and social structure of a given society.

\section{Conclusion}

This paper has attempted to argue that the integrated community development approach is the most effective method to rural development in Nigeria. It further argued that the current approach to rural development is defective because it does not involve the rural dwellers nor does it enable them (Juralites) to build their administrative capacities to be able to met their own needs. As a corollary to the preferred rural development policy, the paper argued that the most appropriate approach for rural development should be obtained from the rural areas. Similarly the paper dismissed the growth oriented development model as being insensitive to the problem of the rural dwellers. It advocates for the integrated community development approach. In other words, the most effective way of developing the rural area is by involving the rural dwellers in the planning and execution of the programmes and projects because in the final analysis it is their projects and not those of the planner that were being executed.

\section{References}

[1]. Ahmadu B. (1979) The role of agriculture in rural development: The mobilize, 31, 10-16.

[2]. Alkali, R.A. (1986) "United States agricultural business: Proletaranization of the peasantry paper presented at the University of Maiduguri, Sociology Staff Seminar Series.

[3]. Agbesi Dan (1979, April, 20) Revolution of the masses. The Nigri Standard xxiv, 15.

[4]. Bala, T. (1980) The strategy for rural development Ibadan Oko press.

[5]. Brewer, CD. (1979). The policy Sciences Emerge to nurture and structure a discipline- Policy Issues Vol.5, $17-23$.

[6]. D'Silva and Kaza (1983). Plan implementation in Nigeria (1962-1976) Ibadan.Nigeria Institute of Social and Economic Research (NISER) and Oxford University press.

[7]. Dada, F.A. (1986) "Shortage in the midst of plenty at Allied Bank", National Workshop on Nigeria Agriculture. January 28d, — 29 ".

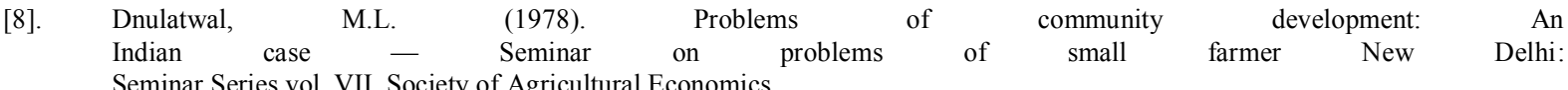

[9]. Dunmaje, A. R. (1986) The state and peasantry. The politics of integrated agricultural development project in Nigeria: Unpublished Ph.D. Thesis University of Ibadaji.

[10]. Gana, Jerry (1984) Diffusion of Agricultural Innovations and Development: A Case Study of Funtua and Mulunfashi Area. Paper presented at Geography Department Seminar. Abmadu Bello University, Zaria, p. 1 - 13 .

[11]. Idachaba F.S. (1980) Concept and strategies of integrated rural development, lessons from Nigeria. Food policy technical Research Paper No. 1, Department of Agricultural Aconomics, University

[12]. Ibadan.

[13]. Nycrere J.K (1968) Ujama'a: Essays on socialism. London_ Oxford University press. 
[14]. Nzongola — Ntalaga (1 989). Revolution and counter-revolution in Africa: Essays on Contemporary politics. Kaduna: Zed Books Ltd.

[15]. Musa, H.B. et' al (1996) Community development and rural transformation in Nigeria. Educational Forum 2 (2) $30-35$.

[16]. Musa, H.B. et' al (1 986). The implication of environmental autonomy of Agric in Nigeria projects. Presented at the $5^{\text {th }}$ Conference of Nigeria Rural Sociological Association (NRA) University of Jos. $3^{\text {rd }}-5^{\text {th }}$ February.

[17]. Musa, H,B. (1995). The Role of Extension in Co-operative management and Administration in Sahel Analyst. 3 (1 and 2), 30-43.

[18]. Ojo, A. (1977) Development challenges of the eighties Lagos: $\mathrm{Nd}$ publishers.

[19]. Olatumbuso D. (1975)Nigeria neglected rural majority. lbadan; NISER/OUP

[20]. Olayide, S.O. (1984) Implementing the national green revolution in Osuntogun A. and Ugorj (eds) in the private sector and Nigeria agricultural development. (pp 80-89) Illorin: Illorin press.

[21]. Omar H. (1987) A Search, for alternative rural development strategy. The social science approach. A paper presented at the Departmental Seminar Series, University of Maiduguri $2^{\text {nd }}$ February.

[22]. Raza, M. (1982) "Basic need approach to rural poverty in Nigeria. In Igbozarka and Raza" (eds) Ilorin: Rural Development in Nigeria and Quality of life.

[23]. Sa'ad and Dicta (1986) "The political economy of Nigeria agricultural programmes. Presented at the Conference of Agricultural and Rural Development, Ile Ife University.

[24]. Van Velzen (1976) "Science technology and production in under developed countries — An Introduction Journal for Development Studies, $9(1), 62-69$.

[25]. World Bank (1984) agricultural sector Trends, issues and strategies: Washington DC: The Developing Countries.

[26]. Musa Haruna Bwala teaches sociology and anthropology in the University of, Maiduguri; Akodi Patrick Okwute teaches business management $\mathrm{n}$ the same University. 